Article

\title{
Production and Evaluation of Composite Rainwater Storage Tanks from Recycled Materials Part 2: Stored Water Quality Assessment
}

\author{
Abel O. Olorunnisola * (D) and Amarachi C. Alaka \\ Department of Wood Products Engineering, University of Ibadan, Ibadan, 2000001, Nigeria; \\ alakamarachi@hotmail.com \\ * Correspondence: abelolorunnnisola@yaho.com
}

Received: 4 April 2018; Accepted: 30 May 2018; Published: 2 June 2018

\begin{abstract}
This paper presents the concluding part of the study on the development cement-bonded composite tanks for rainwater storage. Water containers were fabricated using four composite mixtures (cement + sawdust, cement + sawdust + water sachets, cement + sawdust + acrylic plastic waste, and cement + sawdust + water sachet + acrylic plastic waste) and tested. The quality of the rainwater samples tested immediately after harvesting and samples stored in the composite tanks, a traditional clay pot and a plastic bucket (controls) for four and eight weeks, respectively, were analyzed. The cooling effects of the composite tanks on the stored rainwater were also investigated. Results indicated that the harvested rainwater was free of contaminants. However, there were some preliminary negative interactions between cement and the stored water. Within the first four weeks in storage, the water quality deteriorated with the $\mathrm{pH}$ and total suspended solids exceeding acceptable limits. A marked reduction in the salinity, total hardness, total dissolved solids, electrical conductivity, and turbidity was observed by the eighth week. Acrylic plastic waste particles generally had minimal negative interaction with the stored rainwater. The cooling effects of the tanks were positively correlated with the density and thermal conductivity of the composite materials.
\end{abstract}

Keywords: rainwater; cement-composite; tanks; water quality

\section{Introduction}

The quality of the water supply in human communities is important since it plays a prominent role in determining where people can live, their quality of life, and the extent to which development will occur [1]. However, it is not only water quality that is important in achieving health improvements [2], but also its quantity and storage, which is dependent on accessibility.

The World Health Organization [3] observed that only 32\% of the rural population in developing countries has access to safe drinking water. As noted by Qadri et al. [4] and supported by Lade and Okunlola [4], water scarcity will escalate across the globe to a level that $60 \%$ of the population may experience water scarcity by 2025 . Today, a large percentage of the rural population in developing countries, including Nigeria, continues to live without adequate access to safe and convenient water supply $[5,6]$. This shortfall in water supply has been attributed to numerous factors including climate change, rapid population growth combined with industrialization, urbanization, agricultural intensification, high rate of river and stream pollution from human activities, as well as non-maintenance of existing infrastructural facilities used for water supply and erratic power supply to run the machinery $[7,8]$. Groundwater, which is a popular source of potable water, is facing serious challenges in many parts of Nigeria because it is not properly harnessed and managed [9]. In recent 
times, the increasing pressure is taking a new dimension as residents of many urban and semi-urban areas engage in water supply by distribution tankers, water vendors and rainwater collection system.

Roof top rainwater harvesting system, i.e., collection, storage and eventual use of captured rainwater is one way to addressing the increase in demand for safe water in South-western Nigeria where the annual rainfall reaches $2400 \mathrm{~mm}$ [6]. It is still the only source of un-piped and untreated water for cooking, washing, and drinking in rural communities in the country where there are no water supply networks. It is relatively clean, and the quality is usually acceptable for many purposes with little or no treatment $[6,10,11]$. This is a result of a natural distillation process that is at risk only from airborne particles and from man-made pollution caused by the smoke and ash of fires and industrial processes [10]. Despite the benefits of rainwater harvesting, the opportunities it offers are yet to be fully utilized in many developing countries including Nigeria for different reasons, a major one being storage challenges. A preliminary evaluation of water storage practices in Ibadan city in south-western Nigerian by the authors showed that the different rainwater storage tank materials such as fiberglass, polyethylene, wood, metal, concrete, and ferro-cement have one limitation or the other including cost and durability among others. Also, previous studies indicated that the source of water, type, and color of the storage material, duration and condition of storage, as well as the handling of the storage vessel by users all have effects on the quality of the stored water $[2,6,12-17]$. Water storage materials that have been tested include plastic tanks $[2,6,12,17]$, concrete tanks [2,6,12], metallic tanks $[14,16,17]$, clay pots [14,16,17], calabash [14], and polyethylene barrels [16]. Lade and Okunlola [6] reported that untreated rainwater stored in underground concrete tanks for 28 days may still be potable, while Popoola et al. [2] reported a perceptible smell in treated tap water after 12 weeks of storage in capped plastic containers and prescribed a storage period of $2-4$ weeks. Eniola et al. [12] also recommended a storage period of 10-14 days for potable borehole water, while Ogozige et al. [17] recommended 21 days for both tap and borehole water. Aladenola et al. [18] also reported that rainwater could be stored in sawdust-cement tanks for two months. These studies indicate the suitability of cement/concrete-based materials for rainwater storage and the undesirability of prolonged storage of drinkable water.

Given the relatively high cost of cement and the challenge of urban waste management in Nigeria and many other developing countries. As noted by Aladenola et al. [18], rainwater storage tanks have been produced from inexpensive locally available materials such as mud bricks, stabilized soil, rammed earth, bamboo, and tarpaulin. An alternative, relatively low-cost concrete-based composite storage material produced largely from recycled materials from the urban waste stream is therefore desirable. This is because recycling, i.e., collecting, reprocessing, and/or recovering of waste materials (e.g., glass, metal, plastics, wood, and paper) to make new materials or products, generates numerous environmental and economic benefits. They create jobs and income, supply valuable raw materials to industry and reduce greenhouse gas emissions and the number of landfills and combustion facilities. A candidate material is cement-bonded composite reinforced with recycled wood and plastic waste materials, two of the major solid waste products in Nigeria. The justification for this choice and characterization of the proposed composite material were presented by Alaka and Olorunnisola [19].

The objective of this study, therefore, was to assess the effects of partial replacement of sawdust with water sachet and acrylic plastic waste particles in cement-bonded composites storage tanks produced from gmelina (Gmelina arbrea Roxb.) sawdust on the quality of stored rainwater immediately after harvesting, as well as four week and eight weeks after storage, respectively. The primary goal was to determine the level of leachability of the composite materials into the stored water.

\section{Methodology}

Gmelina sawdust collected from a local sawmill was soaked in water for $24 \mathrm{~h}$ at room temperature (approximately $27.8^{\circ} \mathrm{C}$ ) to remove water-soluble substance(s) that may inhibit the setting of cement. The sawdust was then sun-dried and screened with $1.18 \mathrm{~mm}$ and $850 \mu \mathrm{m}$ sieves. Particles that passed through $1.18 \mathrm{~mm}$ sieve and were retained on the $850 \mu \mathrm{m}$ sieve. Disused water sachets collected from a dump site on the University of Ibadan campus were thoroughly washed and air-dried for a couple 
of days. Acrylic wastes were collected from a company. The sachets and acrylic plastic waste were hammer-milled and sieved. Particles that passed through $1.18 \mathrm{~mm}$ sieve and were retained on the $850 \mu \mathrm{m}$ sieve were used. Type I Portland cement was purchased locally, while potable water sourced from the University of Ibadan water supply was used.

For water quality tests, triplicate prototype samples of $15 \mathrm{~mm}$ thick, 5-lire capacity covered storage tanks were moulded in a set of plywood moulds with the cement-bonded composite materials (Figures 1 and 2). The cement:filler material (sawdust, plastic water sachet, or acrylic waste):water ratio of 4:1:0.5.was kept constant based on preliminary findings reported by Alaka and Olorunnisola [19]. A set of tank samples contained a mixture of cement and sawdust only. In the other experimental samples, sawdust was partially replaced with water sachet and acrylic waste particles by mass as follows: cement + sawdust $(50 \%)+$ water sachet particles $(50 \%)$; cement + sawdust $(50 \%)+$ acrylic plastic waste particles (50\%); and cement + sawdust (50\%) + water sachet particles $(25 \%)+$ acrylic plastic waste particles $(25 \%)$. After being de-moulded, the tanks were cured for 28 days before being tested.

Triplicate units of $13 \mathrm{~mm}$ thick covered traditional laterite clay pots and $3.85 \mathrm{~mm}$ thick covered plastic (Polyvinyl Chloride) buckets were used as controls. The composite tanks, clay pots, and plastic buckets were kept at room temperature in a secluded area. Rainwater, harvested from an asbestos-cement roof on the campus of University of Ibadan, Nigeria, was taken to the laboratory immediately after rainfall for baseline analysis using the WHO standard before storage. The parameters determined were appearance, apparent color, $\mathrm{pH}$, total hardness, total suspended solids, total dissolved solids, dissolved free $\mathrm{CO}_{2}$, electrical conductivity, salinity, and turbidity. Thereafter, $5 \mathrm{~L}$ of the same rainwater was stored in each of the 18 containers for eight weeks to examine the effect of storage duration on harvested rainwater beyond the 28 days reported by Lade and Okunlola [6]. Water samples were collected from each container for at the end of the fourth and the eighth week, respectively, to investigate the effects of the material and duration of storage on the quality of the stored water. The water quality values obtained were compared with the WHO standards for drinking water. Since the evaporative cooling effect of earthen (clay) pots on water is well known [14], the ambient temperature as well as the temperature of the water stored in the clay pots, plastic buckets, and cement-bonded composite tanks were monitored for three consecutive days to compare the cooling effects of the different tank materials.

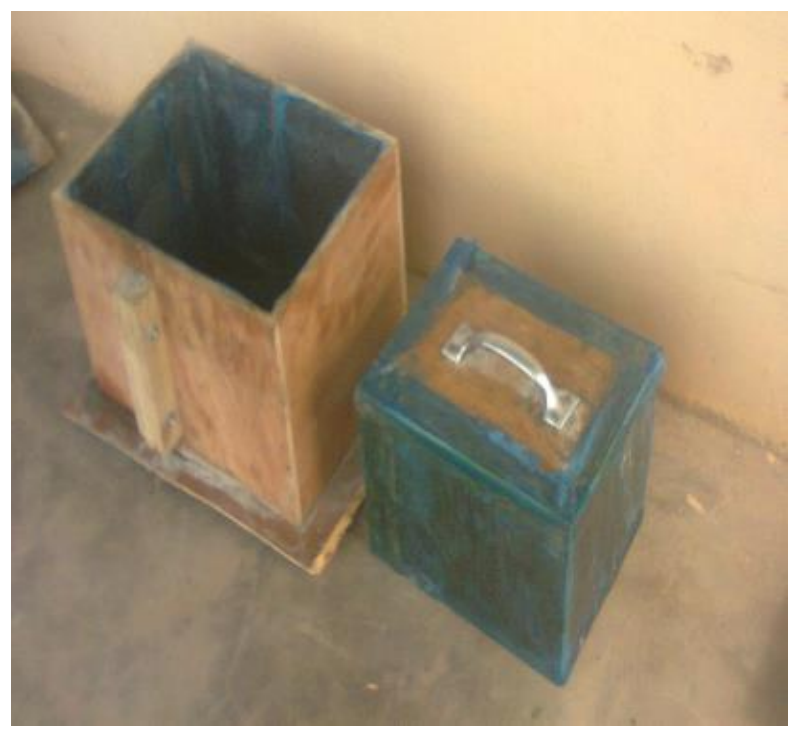

Figure 1. A Sample of the wooden mould used as formwork. 


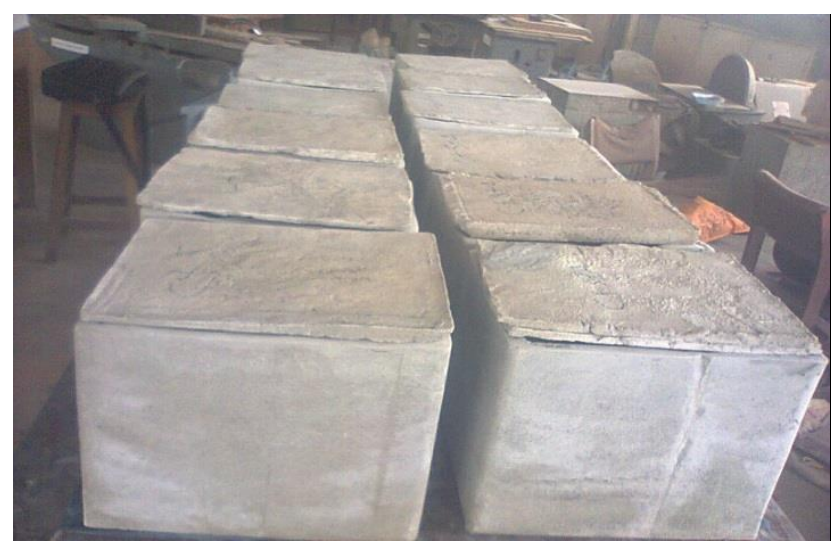

Figure 2. The composite tanks.

\section{Results and Discussion}

\subsection{Quality of the Freshly Harvested Rainwater before Storage}

The quality attributes of the freshly harvested rainwater are presented in Table 1 . The mean $\mathrm{pH}$ (6.3) was lower than the minimum of 6.5 recommended by the WHO for water that is fit for drinking and 6.85 reported by Aladenola [18] for freshly harvested rainwater in Akure, Western Nigeria. The value is, however, comparable to a $\mathrm{pH}$ of 5.9 reported by Ushurhe and Origho [15] for freshly harvested rainwater in Ughelli, Southern Nigeria. The harvested rainwater also had a dissolved free $\mathrm{CO}_{2}$ content of $4.66 \mathrm{mg} / \mathrm{L}$, which is about 10 times higher than the value $(0.4 \mathrm{mg} / \mathrm{L})$ reported by Aladenola et al. [18] for freshly harvested rainwater in Akure. The acidity and presence of dissolved free $\mathrm{CO}_{2}$ in the water sample may be associated either with the status of the asbestos roofing material through which the rainwater was harvested or the prevailing atmospheric conditions. However, the mean salinity $(18 \mathrm{mg} / \mathrm{L})$, total hardness $(22.2 \mathrm{mg} / \mathrm{L})$, conductivity $(52.5 \mu \mathrm{mhos} / \mathrm{cm})$, turbidity (3.48 FTU), and other quality parameters were within acceptable WHO limits as also reported for fresh rainwater by Lade and Okunlola [6] and Ushurhe and Origho [15].

Table 1. Quality attributes of the freshly harvested rainwater before storage.

\begin{tabular}{ccc}
\hline Parameter & Freshly Harvested Rainwater & WHO Limit for Drinking Water \\
\hline Apparent color $\left(\mathrm{K}_{2} \mathrm{PtCl}_{6}\right.$ color units) & 1 & $<10$ \\
Appearance & Clear & Clear \\
$\mathrm{pH}$ & 6.3 & $6.5-8.5$ \\
Salinity $(\mathrm{mg} / \mathrm{L})$ & 18 & 50 \\
Total hardness $(\mathrm{mg} / \mathrm{L})$ & 22.2 & 500 \\
Conductivity $(\mu \mathrm{mhos} / \mathrm{cm})$ & 52.7 & 1500 \\
Free $\mathrm{CO}_{2}(\mathrm{mg} / \mathrm{L})$ & 4.66 & No Recommendation \\
Turbidity (FTU) & 3.48 & 5 \\
Total Dissolved Solids (TDS) $(\mathrm{mg} / \mathrm{L})$ & 39 & 1000 \\
Total Suspended Solids (TSS) $(\mathrm{mg} / \mathrm{L})$ & 39 & 50 \\
\hline
\end{tabular}

\subsection{Quality Attributes of the Rainwater after Four Weeks of Storage}

The quality attributes of the harvested rainwater after four weeks of storage in the six different containers are presented in Table 2. The color and appearance of the water were still within the WHO limits. However, the mean $\mathrm{pH}$ of the water samples in all the six containers had increased within the storage period. In the case of the clay pots and plastic buckets, the mean $\mathrm{pH}$ values had slightly increased from 6.3 to 8.7 and 8.1 respectively, whilst in the case of the cement-bonded composite tanks, the mean $\mathrm{pH}$ had increased to between 10 and 10.6. Hence, except for the samples stored in the plastic buckets, the $\mathrm{pH}$ of all the stored water samples had risen beyond acceptable WHO limits 
for drinking water. This was particularly more so in case of the cement-bonded composite tanks, an indication of an interaction between the cement (largely made up of calcium oxide) and the stored water. The calcium oxide content of the Portland cement must have reacted with the stored rainwater to form carbonates, thereby increasing the $\mathrm{pH}$ of the water since alkalinity is a generic term for carbonates $\left(\mathrm{CO}_{3}{ }^{2-}\right)$, bicarbonates $\left(\mathrm{HCO}_{3}{ }^{-}\right)$, and hydroxides $(\mathrm{OH})[19,20]$. A potential bacteriological implication of the higher increase in the $\mathrm{pH}$ of the water samples in the cement-bonded composite tanks, which was not investigated in this study, is the reduction in the proliferation of bacterial cells. As noted by Sule et al. [13], a neutral $\mathrm{pH}$ tends to support the growth of quite a number of bacteria.

The average salinity of the water samples stored in all the six containers had also increased within four weeks. While the salinity values of the samples stored in the laterite clay pot and plastic buckets (controls) were still below the WHO limit of $50 \mathrm{mg} / \mathrm{L}$ for potable water, the mean values for the samples stored in the four cement-bonded composite tanks had increased to between 50.6 and $68.47 \mathrm{mg} / \mathrm{L}$. In this regard, the tanks fabricated with cement-sawdust-water sachet-acrylic plastic waste composite gave the best result since the salinity value exceeded the WHO limit only very slightly. The relatively large increase in the salinity of the water samples stored in the cement-bonded composite tanks may be attributed to the leaching of some salts from the cement content into the water sample, a situation that was apparently ameliorated in the presence of acrylic plastic waste particles in the composite. It should be noted, however, that the surface:volume ratio of the experimental jar size $(5 \mathrm{~L})$ is relatively high compared to bigger tanks of 2000-10000 L capacity water storage tanks typically encountered in real-life applications and could have amplified the leaching process. Incidentally, none of the previous studies available for review on water storage for this study indicated the size of the storage container for comparison. Also, a determination of the maximum size of water storage structures that could be fabricated with the various composite materials tested was beyond the scope of this study.

Table 2. Quality attributes of the harvested rainwater after four weeks of storage.

\begin{tabular}{|c|c|c|c|c|c|c|}
\hline Parameter * & Tank 1 & Tank 2 & Tank 3 & Tank 4 & Clay Pot & Plastic Bucket \\
\hline $\begin{array}{c}\text { Apparent color } \\
\left(\mathrm{K}_{2} \mathrm{PtCl}_{6} \text { color units }\right)\end{array}$ & 1 & 1 & 1 & 1 & $\begin{array}{c}1 \\
<10\end{array}$ & 1 \\
\hline Appearance & Clear & Clear & Clear & Clear & $\begin{array}{l}\text { Clear } \\
\text { Clear }\end{array}$ & Clear \\
\hline $\mathrm{pH}$ & 10.6 & 10.8 & 10.0 & 10.4 & 8.7 & 8.1 \\
\hline Salinity $(\mathrm{mg} / \mathrm{L})$ & 67.4 & 68.47 & 59 & 50.6 & 26.35 & 20.43 \\
\hline Total hardness (mg/L) & 602 & 527.67 & 372.33 & 238.78 & 48.2 & 25.4 \\
\hline Conductivity $(\mu \mathrm{mhos} / \mathrm{cm})$ & 2087 & 2301.67 & 1330 & 966.67 & $\begin{array}{l}87.8 \\
1500\end{array}$ & 71.3 \\
\hline Free $\mathrm{CO}_{2}(\mathrm{mg} / \mathrm{L})$ & 8.72 & 9.3 & 8.47 & 8.92 & 9.89 & 1.41 \\
\hline Turbidity (FTU) & 16.57 & 8.55 & 6.71 & 7.82 & $\begin{array}{c}14.45 \\
5\end{array}$ & 9.15 \\
\hline $\mathrm{TDS}(\mathrm{mg} / \mathrm{L})$ & 1319.33 & 1284 & 978.33 & 583 & 59 & 39.33 \\
\hline TSS (mg/L) & 109.9 & 39.4 & 288 & 29.83 & $\begin{array}{l}81.35 \\
5-10\end{array}$ & 16.57 \\
\hline
\end{tabular}

LEGEND: Tank 1 = Cement-Sawdust Composite Tank; Tank 2 = Cement-Sawdust-Water Sachet Composite Tank; Tank 3 = Cement-Sawdust-Acrylic Plastic Waste Composite Tank; Tank 4 = Cement-Sawdust-Water Sachet-Acrylic Plastic Waste Composite Tank; * Mean values reported.

The total hardness of all the stored water samples had also increased from $22.2 \mathrm{mg} / \mathrm{L}$ to between $25.4 \mathrm{mg} / \mathrm{L}$ (for water samples stored in the plastic bucket) and $602 \mathrm{mg} / \mathrm{L}$ (for samples stored in the cement-sawdust composite tanks). The hardness values recorded for the cement-sawdust composite tanks were about twice the values reported by Aladenola et al. [18] for rainwater stored in similar containers for two months. The plastic and clay materials did not contribute much to the increase in the total hardness of the stored water samples, the values still remaining below the upper limit of $500 \mathrm{mg} / \mathrm{L}$ specified by WHO for drinking water. Another negative implication of the hardness of the water stored in the cement-sawdust composite tanks is that the water may impair laundry and cause 
discoloration of cooking utensils [13]. Hardness is caused by multivalent metallic cations, particularly calcium and magnesium [20,21]. The calcium and magnesium contents of the cement must have leached into the water samples stored in the cement-bonded composite tanks thereby increasing their hardness. As shown in Table 3, calcium oxide is the major component of Portland cement (60-67\%), while magnesium oxide is generally present in small percentages $(0.1-4.0 \%)$.

Table 3. Approximate composition limits of Portland cement.

\begin{tabular}{cc}
\hline Oxide & Content (\%) \\
\hline $\mathrm{Ca} \mathrm{O}$ & $60-67$ \\
$\mathrm{SiO}_{2}$ & $17-25$ \\
$\mathrm{Al}_{2} \mathrm{O}_{3}$ & $3-8$ \\
$\mathrm{Fe}_{2} \mathrm{O}_{3}$ & $0.5-6.0$ \\
$\mathrm{MgO}$ & $0.1-4.0$ \\
$\mathrm{Alkalis}$ & $0.2-1.3$ \\
$\mathrm{SO}_{3}$ & $1-3$ \\
\hline \multicolumn{2}{c}{ Source: [22]. }
\end{tabular}

The acrylic plastic waste material appeared to have, again, had an ameliorating effect on the interaction between the tank materials and the stored water. The hardness values $(238.78 \mathrm{mg} / \mathrm{L}$ for cement-sawdust-acrylic plastic waste tanks, and $372 \mathrm{mg} / \mathrm{L}$ cement-sawdust-water sachets-acrylic plastic waste tanks) fell within the WHO limit. It was also observed that the higher the acrylic plastic waste content, the lower the total hardness value that was recorded.

By the fourth week, the electrical conductivity of only water samples stored in the cement-sawdust and cement-sawdust-water sachet composite tanks had risen above the WHO limit of $1500 \mu \mathrm{mhos} / \mathrm{cm}$. An increase in the electrical conductivity of rainwater during storage in concrete tanks was also reported by Lade and Okunlola [6]. The increase is another indication of the reaction of cement with the stored rainwater, and the ameliorating effects of the acrylic plastic waste particles in this case. Electrical conductivity is an indication of the presence of dissolved solids and contaminants (cations), in a water sample [23] Ab. initio, the harvested rainwater contained dissolved $\mathrm{CO}_{2}$ which made it unfit "as is" for drinking. Lade and Okunlola [6] had noted that harvested rainwater may sometimes be unsuitable for domestic use but could be considered for irrigation. By the fourth week, dissolved free $\mathrm{CO}_{2}$ had almost doubled in all the cement-bonded composite and clay containers, all of which contained large quantities of organic materials but had reduced in water samples stored in the plastic buckets.

Turbidity consists of fine organic and/or inorganic material suspended in water, causing a cloudy appearance $[20,22]$. As would be expected, therefore, the turbidity of the rainwater samples stored in all the cement-bonded and clay containers had increased above WHO limit of 5 FTU by the fourth week due to the reaction of the organic contents of the storage materials with the stored water. No such increase in turbidity was reported by Lade and Okunlola [6] for harvested rainwater samples stored in concrete tanks at 28 days. However, the total dissolved solids in the water samples stored in only the two cement-bonded composite containers devoid of acrylic plastic waste had increased beyond the WHO limit. Interestingly though, the total suspended solids of the water samples had increased above WHO limit of $50 \mathrm{mg} / \mathrm{L}$ in the cement-sawdust and cement-sawdust-acrylic plastic waste containers as well as the clay pots.

\subsection{Quality Attributes of the Rainwater after Eight Weeks of Storage}

Between the fourth and the eighth week, the water samples in the replicated clay pots and the cement-sawdust tanks as well as one of the cement-sawdust-acrylic tanks had dried off. Hence, subsequent quality analysis was restricted to the water samples in the remaining cement-bonded composite tanks and the plastic buckets. The results, presented in Table 4, showed that after eight weeks, the color and appearance of water samples in the remaining cement-bonded and plastic 
containers were still within the WHO limits. The salinity, total hardness, total dissolved solids, electrical conductivity, and turbidity of the water samples stored in the cement-bonded composite tanks had reduced dramatically, thereby meeting the WHO standard for drinking water. The total hardness of the water samples in the remaining cement-bonded composite tanks compared favorably with the values (230-300 mg/L) reported by Aladenola et al. [18] for rainwater stored for eight weeks in similar cement-bonded containers fabricated with sawdust of Gmelina arborea. These results are an indication of the positive effect of prolonged storage in these containers on the quality of the stored rainwater.

Table 4. Quality attributes of the harvested rainwater after eight weeks of storage.

\begin{tabular}{|c|c|c|c|c|c|c|}
\hline Parameter & Tank 1 & Tank 2 & Tank 3 & Tank 4 & Clay Pot & Plastic Bucket \\
\hline $\begin{array}{c}\text { Apparent color } \\
\left(\mathrm{K}_{2} \mathrm{PtCl}_{6} \text { color units }\right)\end{array}$ & $\mathrm{N} / \mathrm{A}$ & 1 & 1 & 1 & $\mathrm{~N} / \mathrm{A}$ & 1 \\
\hline Appearance & $\mathrm{N} / \mathrm{A}$ & Clear & Clear & Clear & $\mathrm{N} / \mathrm{A}$ & Clear \\
\hline $\mathrm{pH}$ & $\mathrm{N} / \mathrm{A}$ & 10.5 & 10.4 & 9.2 & $\mathrm{~N} / \mathrm{A}$ & 8.56 \\
\hline Salinity $(\mathrm{mg} / \mathrm{L})$ & $\mathrm{N} / \mathrm{A}$ & 51.63 & 46.9 & 34.03 & $\mathrm{~N} / \mathrm{A}$ & 12.93 \\
\hline Total hardness (mg/L) & $\mathrm{N} / \mathrm{A}$ & 220 & 190 & 135.67 & $\mathrm{~N} / \mathrm{A}$ & 21.6 \\
\hline Conductivity $(\mu \mathrm{mhos} / \mathrm{cm})$ & $\mathrm{N} / \mathrm{A}$ & 1235.33 & 732 & 297 & $\mathrm{~N} / \mathrm{A}$ & 68.13 \\
\hline Free $\mathrm{CO}_{2}(\mathrm{mg} / \mathrm{L})$ & $\mathrm{N} / \mathrm{A}$ & 3.15 & 2.48 & 1.64 & $\mathrm{~N} / \mathrm{A}$ & 0.64 \\
\hline Turbidity (FTU) & $\mathrm{N} / \mathrm{A}$ & 4.87 & 4.87 & 3.98 & $\mathrm{~N} / \mathrm{A}$ & 8.22 \\
\hline TDS $(\mathrm{mg} / \mathrm{L})$ & $\mathrm{N} / \mathrm{A}$ & 826 & 500.5 & 191.67 & $\mathrm{~N} / \mathrm{A}$ & 37.67 \\
\hline TSS (mg/L) & $\mathrm{N} / \mathrm{A}$ & 107.2 & 230 & 59.7 & $\mathrm{~N} / \mathrm{A}$ & 12.9 \\
\hline
\end{tabular}

LEGEND: Tank 1 = Cement-Sawdust Composite Tank; Tank 2 = Cement-Sawdust-Water Sachet Composite Tank; Tank 3 = Cement-Sawdust-Acrylic Plastic Waste Composite Tank; Tank 4 = Cement-Sawdust-Water Sachet-Acrylic Plastic Waste Composite Tank; N/A = Result Not Available.

The water samples stored in the acrylic plastic waste composite tanks again exhibited the lowest hardness. However, the $\mathrm{pH}$ and Total suspended solids were still higher than the upper limit of 8.5 stipulated by the WHO. This result is contrary to the $\mathrm{pH}$ range of 6.9-7.2 reported by Aladenola et al. [18], perhaps due to the type of cement used. Interestingly, the mean $\mathrm{pH}$ values of the rainwater samples stored in the plastic buckets had also slightly increased from 8.1 to 8.6 within the period. A similar increase in the $\mathrm{pH}$ of bore hole water during storage in plastic containers over a period of 12 weeks was observed by Eniola et al. [12], an indication of an interaction between water and the storage material.

\subsection{The Cooling Effects of the Containers on the Stored Water Samples}

The mean temperature of the water samples stored in the six different containers and the temperature drop in each container are shown in Figures 3 and 4. The samples stored in the plastic buckets had the highest mean temperature of $27.2^{\circ} \mathrm{C}$ and a temperature drop of $1.4{ }^{\circ} \mathrm{C}$, while samples stored in the clay pots had the lowest mean temperature of $25.1^{\circ} \mathrm{C}$ and a temperature drop of $3.4^{\circ} \mathrm{C}$. The cooling effects of the cement-bonded containers were in the following order: cement-sawdust tank $>$ cement-sawdust-acrylic plastic waste tank > cement-sawdust-water sachet-acrylic plastic waste tank $>$ cement-sawdust-water sachet tank. As shown in Figures 5 and 6, the temperature drops correlated positively and strongly with the densities $\left(R^{2}=0.95\right)$ and thermal conductivities $\left(R^{2}=0.88\right)$ of the composite materials already reported by Alaka and Olorunnisola [19] in Part One of this study. 


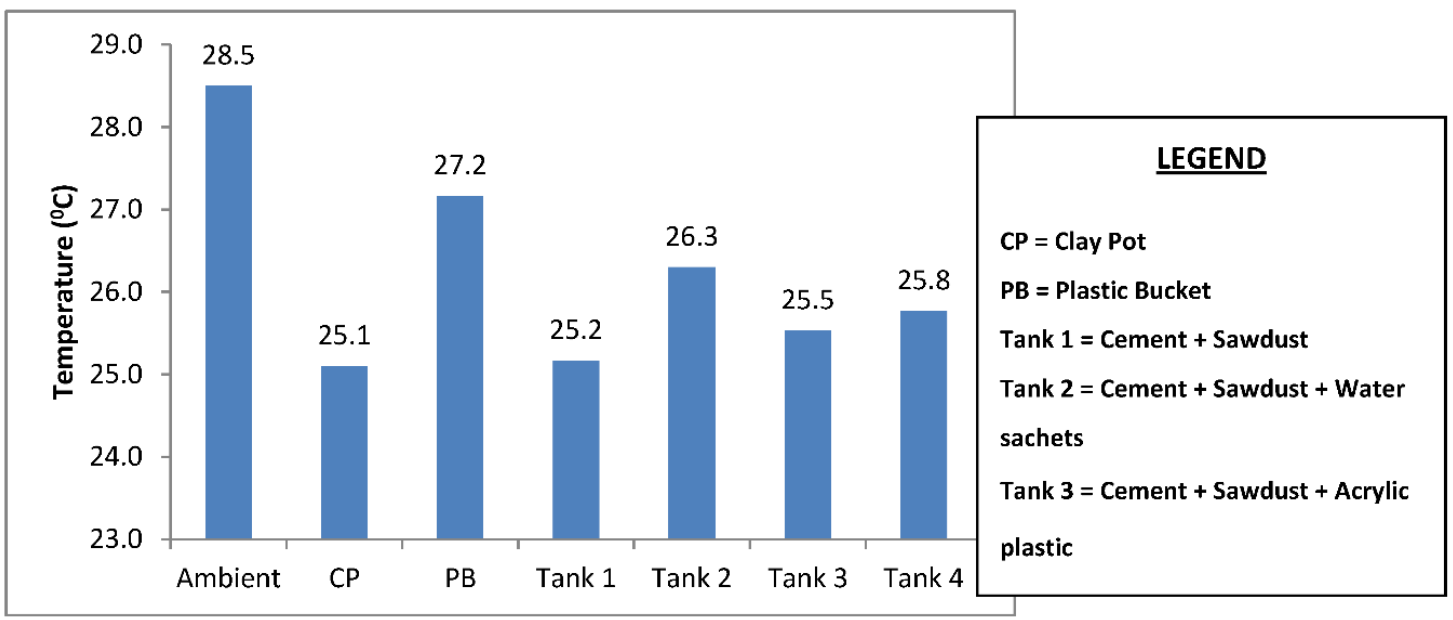

Figure 3. Mean temperature of the rainwater samples stored in the different containers.

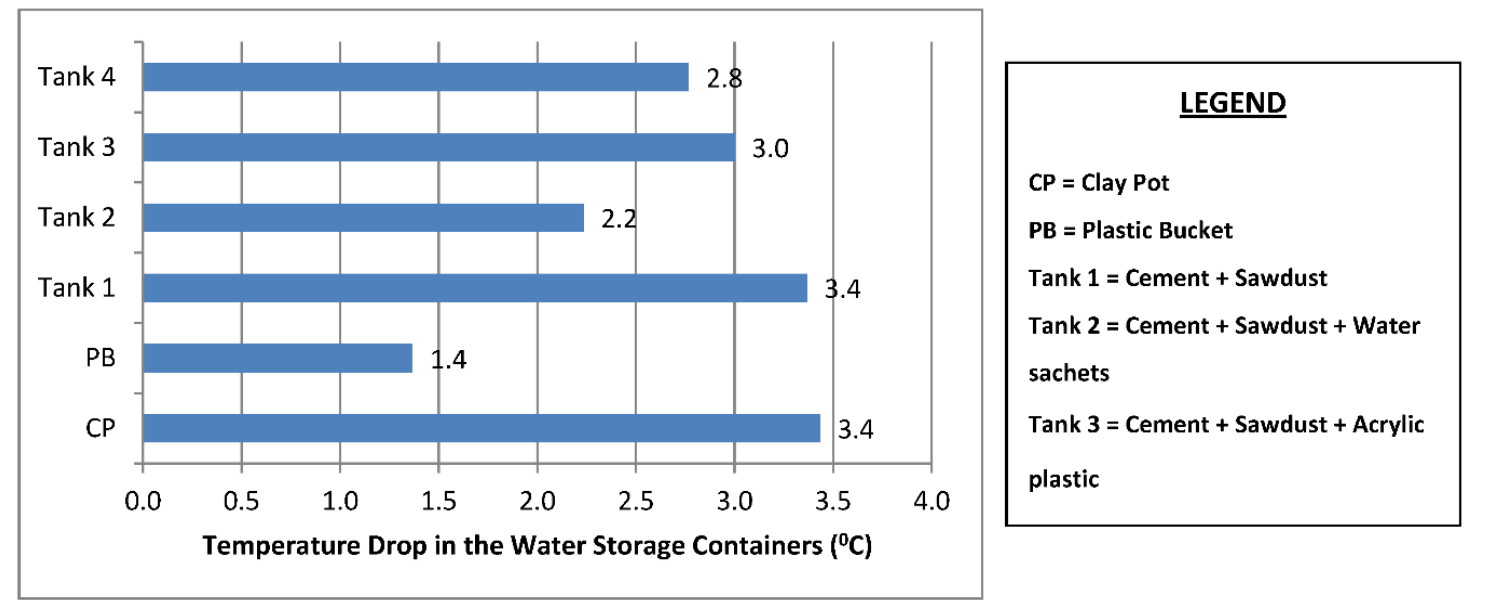

Figure 4. Temperature drop in the rainwater samples stored in the different containers.

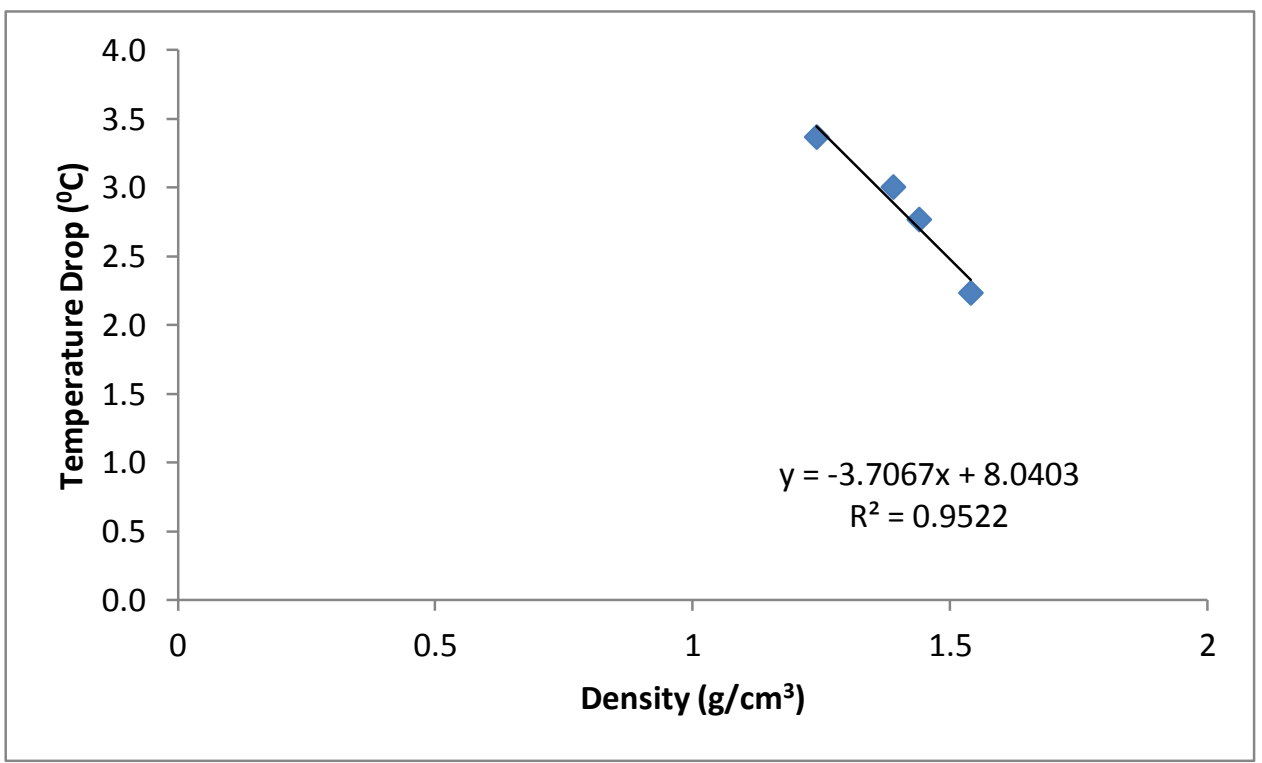

Figure 5. Correlation between density of the tank material and temperature drop in the stored rainwater samples. 


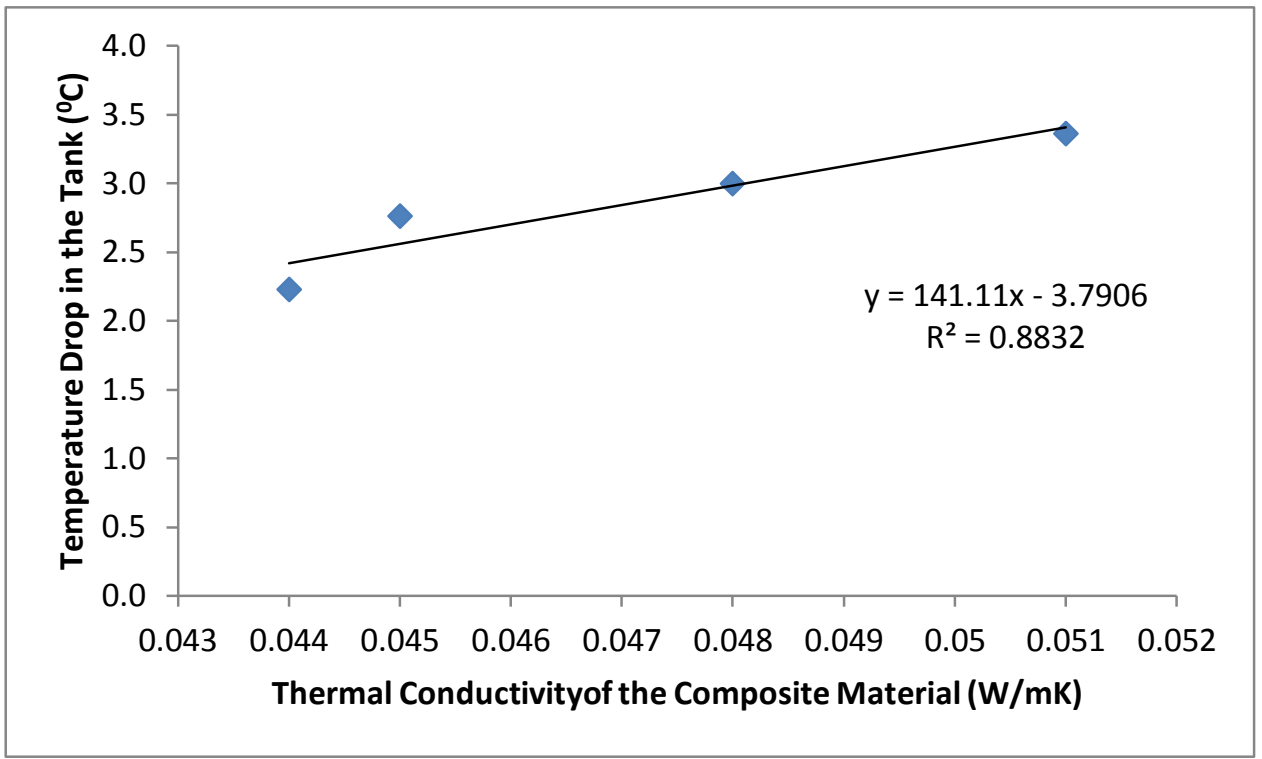

Figure 6. Correlation between thermal conductivity of the tank material and temperature drop in the stored rainwater samples.

The feasibility of local manufacturing of sawdust-cement composite tanks in Nigeria

The local manufacturing of sawdust-cement composite tanks for rainwater storage in Nigeria is feasible given the following factors as noted by Olorunnisola [24]:

Availability of Residues: Sawdust is available in sufficient quantities required for industrial production of wood-cement particleboard in different parts of the country where over 1000 sawmills generate yet to be fully quantified millions of cubic meters of sawdust annually. The bulk of the sawdust presently attracts little or no significant commercial value. It is possible, therefore, to manufacture sawdust-cement composite tanks in areas where large volumes of sawdust are generated.

Availability of Supplementary Cementitious Materials: Portland cement is typically used in making sawdust-cement composites and the general purpose Portland cement is acceptable. However, the cost of cement has continued to escalate in the country in recent times. One of the possible ways of addressing this challenge is the use of supplementary cementitious materials derived from industrial and agricultural waste materials (fly ash, rice husk ash, and corn cob ash) as partial replacement for cement. Recycling these wastes in large quantities as supplementary cementitious materials is also a means of addressing the challenges of environmental pollution.

Adaptability of the production technology: The production technology for sawdust-cement composite production is rather very simple and adaptable to the prevailing climatic and economic conditions in Nigeria.

\section{Conclusions}

Cement-bonded composite rainwater storage tanks were constructed from recycled waste materials mixed with cement and formulated into four different composite mixtures (cement + sawdust, cement + sawdust + water sachets, cement + sawdust + acrylic plastic waste, and cement + sawdust + water sachet + acrylic plastic waste) and tested. Laboratory analyses showed that the overall quality of harvested rainwater initially deteriorated to varying degrees in the different composite containers within the first four weeks of storage. However, there was a marked reduction in the salinity, total hardness, total dissolved solids, electrical conductivity, and turbidity between the fourth and the eighth week. Containers fabricated with acrylic plastic waste exhibited minimal negative interaction with the stored rainwater. The cooling effects of the tanks were positively correlated with the densities and thermal conductivities of the composite materials. It was concluded that an incorporation of acrylic 
plastic waste in cement-sawdust composite tank production for short- to medium-term rainwater storage is feasible and beneficial. Further investigations on production costing and a determination of the maximum size of storage structures that could be fabricated with the composite material are recommended.

Author Contributions: The first author conceived the research idea, supervised the study and worked extensively on preparing the manuscript for publication. The second author conducted the laboratory study and analysis under supervision and contributed to manuscript preparation.

Funding: This research received no external funding.

Conflicts of Interest: The authors declare no conflicts of interest.

\section{References}

1. Solley, W.B.; Pierce, R.R.; Perlman, H.A. Estimated use of water in the United States in 1995. Available online: http://pubs.er.usgs.gov/usgspubs/cir/cir1200h (accessed on 5 May 2018).

2. Popoola, T.O.S.; Shittu, A.O.B.; Lemo, O.O. Physico-chemical changes and bacteriological deterioration of potable water during long term storage. ASSET J. 2007, 6, 51-59.

3. WHO. WHO and UNICEF Joint Monitoring Programme for Water Supply and Sanitation. In Progress on Sanitation and Drinking Water; A publication of the World Health Organisation: Geneva, Switzerland, 2010.

4. Qadir, M.; Sharma, B.R.; Bruggeman, A.; Choukr-Allah, R.; Karajeh, F. Non-conventional water resources and opportunities for water augumentation to achieve foor security in water scarce countries. Agric. Water Manag. 2007, 87, 2-22. [CrossRef]

5. Dada, A.C. Sachet water phenomenon in Nigeria: Assessment of the potential health impacts. Afric. J. Microbiol. Res. 2009, 3, 15-21.

6. Lade, O.; Okunlola, O. Rainwater Quality in Ibadan (Nigeria): Effect of short term storage in surface and underground tanks. World J. Res. Rev. 2017, 5, 6-13.

7. Olokesusi, F. A survey of indigenous water management and coping mechanisms in Africa: Implications for knowledge and technology policy. Presented at the ATPS/EIIPD Conference on Science, Technology' Water and Environment in Africa, Addis Ababa, Ethiopia, 20 November-3 December 2004.

8. Olaoye, R.A.; Olaniyan, O.S. Quality of rainwater from different roof materials. Int. J. Eng. Technol. 2012, 2, 1413-1420.

9. Efe, S.I. Quality of rainwater harvesting for rural Communities of Delta State, Nigeria. Environmentalist 2006, 26, 175-181. [CrossRef]

10. Sridhar, M.K.C.; Coker, A.O.; Adegbuyi, S.A. Rainwater harvesting in Nigeria: Prospects and problems. In Proceedings of the 10th International Rainwater Catchment Systems Conference, Mannheim, Germany, 10-14 September 2001; p. 122.

11. Lade, O.; Oloke, D. Rainwater harvesting in Ibadan city, Nigeria: Socio-economic survey and common water supply practices. Am. J. Water Res. 2015, 3, 61-72. [CrossRef]

12. Eniola, K.I.T.; Obafemi, D.Y.; Awe, S.F.; Yusuf, I.I.; Falaiye, O.A.; Olowe, A.O. Effects of container and storage conditions on bacteriological quality of borehole water. Nat. Sci. 2007, 5, 1-6.

13. Sule, I.O.; Agbabiaka, T.O.; Akomolafe, A.V. Bacteriological quality of water stored in storage tanks. Res. J. Environ. Sci. 2011, 5, 603-610. [CrossRef]

14. Duru, M.; Amadi, C.; Amadi, B.; Nsofor, C.; Humphrey, N. Effect of different torage vessels on water quality. Global Res. J. Sci. 2013, 2, 9-13.

15. Urshurhe, O.; Urigho, T. A comparative assessment of the quality of harvested rainwater, underground water and surface water for domestic purposes in Ughelli, Southern Nigeria. J. Environ. Earth Sci. 2013, $3,9-13$.

16. Akuffo, I.; Cobbina, S.J.; Alhassan, E.H.; Nkoom, M. Assessment of the quality of water before and after storage in Nyankpala community of the Tolon-Kumbungu District, Ghana. Int. J. Sci. Technol. Res. 2013, 2, 221-227.

17. Ogbozige, F.J.; Ibrahim, F.B.; Adie, D.B. Variation in quality of stored potable water in different container materials. In Proceedings of the Materials Science and Technology Society of Nigeria Congress, Uyo, Akwa Ibom State, Nigeria, 22-26 November 2015; pp. 158-171. 
18. Aladenola, O.O.E.; Ajayi, A.E.; Olufayo, A.A.; Ajayi, B. Assessment of Gmelina arborea sawdust-cement-bonded rainwater storage tank. Environmentalist 2008, 28, 123-127. [CrossRef]

19. Alaka, A.C.; Olorunnisola, A.O. Production and Evaluation of Composite Rainwater Storage Tanks from Recycled Materials Part 1. Rec. J. 2018, 3, 1-9.

20. Osmonics. Pure Water Handbook; Osmonics Inc.: Minnetonka, MN, USA, 1991.

21. Davis, M.L.; Cornwell, D.A. Introduction to Environmental Engineering; McGraw-Hill Inc.: New York, NY, USA, 1991.

22. Niville, A.M.; Brooks, J.J. Concrete Technology; Dorling Kindersley: New Delhi, India, 2006.

23. Ojo, O.M. Harvested rainwater quality: A case study of Aule in Akure, South Western Nigeria. Eur. Sci. J. 2016, 12, 451-462.

24. Olorunnisola, A.O. The Potentials of Agricultural Residues as Low Cost Building Materials in Nigeria. In Proceedings of the Humboldt International Conference on Building a Non-Oil Based Economy for Nigeria: The Potentials of Value-Added Products from Agricultural Residues (Humboldt-Kolleg-Ogbomoso), Ladoke Akintola University of Technology, Ogbomoso, 11-14 January 2010; pp. 269-277.

(C) 2018 by the authors. Licensee MDPI, Basel, Switzerland. This article is an open access article distributed under the terms and conditions of the Creative Commons Attribution (CC BY) license (http://creativecommons.org/licenses/by/4.0/). 